\title{
EPISTEMOLOGIA EM DEBATE: UMA BREVE REFLEXÃO ACERCA DO POSITIVISMO, DO MARXISMO E DA NOVA HISTÓRIA
}

\section{ENSAIO TEÓRICO}

GIESBRECHT, Daniel Florence ${ }^{1}$

GIESBRECHT, Daniel Florence. Epistemologia em debate: Uma breve reflexão acerca do positivismo, do marxismo e da nova história. Revista Científica Multidisciplinar Núcleo do Conhecimento. Ano 05, Ed. 11, Vol. 17, pp. 58-82. Novembro de 2020. ISSN: 2448-0959, Link de acesso: https://www.nucleodoconhecimento.com.br/historia/epistemologia-emdebate

\section{RESUMO}

Este estudo pretende discorrer a respeito dos principais paradigmas que norteiam a produção do conhecimento histórico. Para isso, propõe-se a utilização de uma análise qualitativa das três grandes correntes da epistemologia e da filosofia da História: o Positivismo, o Marxismo e a Nova História, assim como suas relações e influências, diretas ou indiretas, na produção do discurso historiográfico. Adotando o critério cronológico e referenciais bibliográficos de autores clássicos do pensamento histórico para explicar a estruturação de tais paradigmas, pretende-se no primeiro momento discutir a maneira de como se produziu a historiografia desde a Idade Média, com a sua História teológica, perpassando pela modernidade através da filosofia cartesiana. No segundo momento, demonstraremos as discussões que prevaleceram no século XIX, momento em que a História se consolida como ciência e que também sofre os impactos da filosofia Positivista e Marxista. Por fim, já no século XX, momento em que se observa uma maior plasticidade metodológica da História, já sob a influência do

${ }^{1}$ Doutorando em História (Universidade de Coimbra), Mestrado em Educação (PUCCampinas), Licenciatura em Ciências Sociais (Unimes), Licenciatura em Pedagogia (FIA), Licenciatura em História (PUC-Campinas). 
movimento dos Annales, discute-se a importância deste, além de suas correlações e críticas realizadas à produção historiográfica.

Palavras-chave: História, Epistemologia da História, Teoria da História, Filosofia da História.

\section{INTRODUÇÃO}

Como em nenhum outro momento, a História hoje se caracteriza por uma completa ausência de consenso. As imprecisas fronteiras entre a economia, a sociedade, a política e a cultura, tornaram-se obsoletas. Ao mesmo tempo, e salienta-se aí mais um paradoxo, vivemos a multiplicação de pesquisas que perdem a dimensão de conjunto e que, renunciando à edificação de qualquer totalidade, retraem-se acabrunhadas às particularidades de seus objetos. Ao lado da excessiva fragmentação, assiste-se a uma não menos inquietante plasticidade metodológica. Os historiadores e professores lançam mão de conceitos polêmicos sem muito critério: consciente/inconsciente coletivo, mentalidades, imaginário, cultura e representação, para ficarmos nos mais atuais.

A operação reflexiva do historiador aproximou-o tanto da diversidade como da pluralidade, características de nossa complexa sociedade. Como observou Demo (1997), o fator principal do conhecimento pós-moderno é seu caráter desconstrutivo. Observa-se atualmente que, em vez do conhecimento produzir certezas, acaba por desmontá-las.

A fértil aproximação da História com a Antropologia e a Linguística, registrada pelo menos desde a década de 1960, trouxe novas interrogações e conceitos, ampliando o universo da ação política e da intervenção social. A cultura, tratada basicamente até então em sua vertente erudita, facilmente observada na obra de Burckhardt (1990), foi buscada entre os grupos subalternos, em suas ramificações populares e nas interrelações com a cultura das elites e contemplada com as obras de Thompson (1981), Burke (1989), Vovelle (1983), dentre outros. 
A problematização do cotidiano, intensificada principalmente com a terceira fase dos Annales, representou uma guinada em direção a temas considerados prosaicos: cumprimentos, etiqueta, alimentação, comunicação oral, gestualização e sexualidade. Em torno desses temas, os pesquisadores procuraram estabelecer nexos e desvendar articulações sociais tão determinantes e decisivas para a vida coletiva quanto às conjunturas econômicas ou estruturas sociais.

$\mathrm{Na}$ busca de significados e do funcionamento das sociedades, as mais diversas linguagens tornaram-se objetos privilegiados para análise, vistas cada vez mais como metáforas da realidade. Os variados discursos (escritos, orais, arquitetônicos, urbanísticos, iconográficos, musicais, gestuais e rituais) passaram a ser decodificados com maior frequência, procurando-se apreender seus elementos de tensão social e seus sentidos históricos, sua produção e sua circulação num dado meio social.

Dito de outra forma, registrou-se a expansão do território tradicional da política e das lutas sociais, dos lugares mais evidentes (estado, sindicatos, partidos, associações) para áreas às quais até então não se atribuía grande relevância (escola, família e cultura). Ou seja, a identificação de elementos da micro história, como mostra Levi (1992), tem sua valorização diante da tradicional macro história. A história sociocultural impõe, nesse sentido, uma revalorização da política e sua identificação em todas as tramas do tecido social.

Ao mesmo tempo em que se registra tal redirecionamento entre os estudos históricos, opera-se um alargamento das lutas sociais na sociedade contemporânea. No Brasil, como em diversas outras regiões do planeta, assiste-se à multiplicação de movimentos que requerem o estabelecimento de garantias legais e a implementação de políticas públicas que erradiquem discriminações e condições sociais que possibilitam a degradação da convivência humana.

Essa verdadeira "era dos direitos" compreende a luta contra os preconceitos raciais, religiosos, sexuais, físicos, regionais e estéticos, dentre tantos outros. Não se trata mais de afirmar os direitos naturais do homem[2], e sim de estabelecer mecanismos de proteção e defesa dessas regras para a vida coletiva. Direitos do homem, em suma, 
cuja história foi marcada pelas diversas lutas em defesa de liberdades contra velhos poderes e privilégios de classes e de grupos sociais (BOBBIO, 1992).

Por mais que toda a História seja embasada em determinada epistemologia e apresente diferentes visões de mundo, de processos e também diferentes transposições ideológicas, ela depende da narrativa. A partir dela, toda a construção lógica do fazer do historiador se torna historiografia e, por conseguinte, uma visão do todo.

Nas próximas páginas, identificaremos os principais paradigmas historiográficos que permeiam a produção do conhecimento histórico, dando especial atenção à História Tradicional/Positivista, ao Marxismo e à Nova História, tendo em vista que, no campo epistemológico, essas são as três maiores influências.

\section{SOBRE AS ORIGENS DO PARADIGMA TRADICIONAL}

Poderíamos questionar as origens dessa forma de pensamento fragmentada que vem dominando as ciências, inclusive a História, mas seria muito difícil estabelecer um marco inicial isolado que tivesse provocado tamanha influência nesse tipo de percepção do mundo. Podemos dizer que esse pensamento é fruto de diversos fatores, principalmente no âmbito filosófico da civilização ocidental, dentre eles a revolução científica, o iluminismo, a revolução industrial e, mais tarde, o positivismo.

Durante a Idade Média europeia, que em termos cronológicos vai do século $V$ ao $X V$, a visão de mundo que prevalecia era orgânica. A realidade para o homem medieval era sagrada e inviolável, cabendo a este agir sobre o mundo de forma contemplativa e harmônica, de acordo com as vontades do criador. Segundo Duby (1989), cabia à igreja o monopólio cultural e, consequentemente, a interpretação da realidade social. Esse domínio também era garantido por meio do controle do tempo. O homem era integrante de uma natureza assustadora e incontrolada, cujas forças desconhecidas o aterrorizavam, pondo-o em situação de desvantagem. As interpretações religiosas o fortaleciam, equilibrando sua posição em relação ao mundo natural. As relações sociais se davam de forma estamental. Aos clérigos cabia a oração, ou seja, zelar 
pelas tradições cristãs; aos nobres, cabia a guerra, já que esta funcionava como atividade econômica; aos servos, o trabalho. Durante o dia o homem exercia suas atividades de acordo com sua posição social e durante a noite descansava, pois fora de sua casa corria o risco de cair em alguma cilada preparada pelos "seres malignos". O tempo dos contrastes da natureza era assim subordinado ao tempo religioso (LE GOFF, 1983).

A História da humanidade dividia-se em duas: antes e depois da vinda do salvador. $\mathrm{O}$ ano era orientado segundo os principais atos do drama do filho de Deus e, a partir do controle do tempo, a igreja definia ações e comportamentos. A dominação da Igreja atingiu os diversos setores da vida e da sociedade, influenciando artística e cientificamente a época. É nesse campo cultural que se desenvolveria a "História teológica".

A História, segundo a vontade de Deus de Gênesis até o Apocalipse, era uma História escatológica. O processo histórico pelo qual passava a humanidade era justificado segundo o plano divino, semelhante ao mito.

Durante a Idade Média, somente os membros do clero tinham acesso à cultura letrada, pois eram os únicos que detinham o monopólio da escrita. A História já havia encontrado seu narrador. Pessoas influenciadas pela mentalidade da época refletiam essa ideologia na forma da historiografia. A vida de um santo, uma igreja, um mosteiro, o tema era sempre o mesmo: a religião. Segundo Borges (2003: 22) "a realidade agora está dividida em dois planos: o superior, perfeito (representado por deus), e o inferior, imperfeito (representado pelos homens)".

$\mathrm{Na}$ História escrita do período medieval, o rigor científico quase inexistia. Só não inexistia totalmente porque os escritos apresentam dados que ajudam a compreensão da realidade da época. Por exemplo, ao estudarmos o papel dos mosteiros na sociedade medieval, podemos reconhecer ligações com a cultura da Antiguidade. $O$ latim era utilizado nas conversas diárias e as práticas da medicina grega eram preservadas. Ali também os livros da literatura clássica, escritos em papiros, eram transferidos pelos copistas para pergaminhos mais resistentes e, apesar do caráter 
eminentemente religioso, os mosteiros constituíram redutos que ajudaram na preservação da própria História europeia.

O rigor crítico das obras medievais é pequeno, não apresentando a preocupação de averiguar a veracidade dos fatos. No imaginário medieval habitavam lendas fantásticas ligadas ao pensamento religioso do período, que refletiram na forma de se escrever a História: reinos perdidos, paraíso terrestre, abismos marítimos, bestas e demônios faziam parte do pensamento cotidiano.

Além do tempo clerical, outra forma de tempo, outro ritmo de vida, começou a formarse na Europa a partir do século XI, com o ressurgimento das cidades. Era o tempo da produção artesanal, das trocas comerciais, do trabalho assalariado. Tempo dos negócios e do trabalho humano, que requeria maior exatidão, maior precisão. Nos séculos XIV e XV, os primeiros relógios mecânicos começaram a se espalhar pela Europa e popularizou-se a divisão do dia em vinte e quatro horas. O tempo leigo começava a afirmar-se perante o tempo religioso dos sinos das igrejas. Um novo paradigma começava a surgir, e, com ele, uma nova forma de pensar a História.

A partir dos séculos XVI e XVII, a natureza da ciência medieval começava a sofrer mudanças radicais. A visão de um mundo orgânico, vivo, espiritual e encantado passou a ser substituída pela noção de um mundo-máquina, composto de objetos distintos, em virtude das mudanças revolucionárias na física e na astronomia ocorridas depois de Copérnico, Galileu, Newton (MORAES, 1997, p. 33).

De acordo com Barreto (1983), uma alteração de sensibilidade começou a pronunciarse no século $\mathrm{XV}$, com a valorização da cultura clássica, do racionalismo e do espírito crítico, ameaçando o controle da igreja. O desenvolvimento da nova cultura correspondia às necessidades da burguesia de se firmar no interior de uma sociedade dominada pela cultura clerical. Além do prestígio político que adquiriam no interior das cidades, esses comerciantes contribuíram para a formação de um movimento cultural alternativo, conhecido como Renascimento, que atingiu seu apogeu entre os séculos XV e XVI. 
Era o início da Idade Moderna, tempo em que o homem estava se reposicionando no interior da sociedade e se tornando o centro de seu significado histórico. Esse novo modelo de ciência colocava o homem como centro do universo, capaz de entender o mundo por inteiro, como se este fosse uma grande máquina a ser observada e medida. Até mesmo os pensadores da igreja já estavam concordando com a ideia de que o mundo, criado por Deus, poderia ser compreendido pelo homem.

São Tomás de Aquino (1225-1274) foi um dos principais nomes da igreja a procurar justificar as novas mudanças ocorridas no campo cultural europeu, tentando conciliar a fé e a razão. Segundo ele, a especulação filosófica podia provar a existência de Deus e a imortalidade da alma humana. Considerava que a revelação não era inimiga da razão, pois era outro caminho para Deus. No mundo haveria toda uma gama de conhecimentos não revelados pelo criador e estes não seriam necessários à salvação. Nessa categoria, enquadrava-se grande parte do conhecimento sobre o mundo natural das coisas e das criaturas que os seres humanos teriam perfeita liberdade de explorar e compreender. A Europa começaria a vivenciar um período que ficou conhecido como Revolução Científica.

(...) Começou quando Nicolau Copérnico se opôs à concepção geocêntrica de Ptolomeu e da Bíblia, aceita por mais de mil anos. Copérnico concluiu, ainda sob a influência do pensamento medieval, que o sol ocupava a posição central do sistema planetário, o que, para ele, simbolizava a "Luz de Deus", a presença divina no universo (MORAES, 1997, p. 34)

Galileu Galilei (1564-1642), grande nome do renascimento italiano introduziu em suas experiências a descrição matemática da natureza e o empirismo como caminho ao conhecimento seguro. Nascia a visão de mundo-máquina, da explicação matemática da realidade, paradigma que permearia o processo de construção do saber histórico e que perdura até hoje.

Com René Descartes (1596-1650), filósofo do século XVII, o conhecimento científico se baseava no fundamento indutivo e só por meio da razão é que chegaríamos à verdade. Para ele, o conhecimento era obtido pela intuição e dedução e a análise 
mostrava o caminho verdadeiro para o qual fora inventada, ao mesmo tempo em que revelava que os efeitos dependiam de suas causas.

Mas foi com Isaac Newton (1643-1727) que o pensamento moderno deu seu grande salto. Ele conseguiu, com sua teoria, solidificar a visão mecanicista do cosmo ao desenvolver uma completa formulação matemática da natureza.

De acordo com Newton, Deus criou as partículas materiais, a força entre elas e as fundamentais do movimento. Tudo isso funciona como uma máquina governada por leis imutáveis, controla a natureza e leva a ciência a pressupor a existência do determinismo universal, ou seja, o universo funciona sempre da mesma maneira (MORAES, 1997, p. 37).

A narrativa de mundo pronto, acabado, regido por leis imutáveis, iria influenciar a produção do conhecimento histórico. O esforço do historiador seria o de selecionar os documentos mais significativos, situá-los no tempo e no espaço e criticá-los quanto ao grau de veracidade e credibilidade. A História latente engendrava-se ao movimento pendular de relógio, de mundo organizado e, portanto, seria também regida por leis universais. A História tradicional encontrava nesse momento o seu embrião, que se desenvolveria com o iluminismo e conquistaria sua aura magna no positivismo.

Narrativas lineares de um tempo ininterrupto, progressivo e da razão humana. Para os iluministas, a História teológica fazia parte de um passado tenebroso, o qual ficou conhecido como "Idade das Trevas".

Em meio a essa modernidade, a História seria embasada e norteada pela razão, pela averiguação e pela veracidade dos fatos, além da cooperação com novas técnicas e ciências auxiliares, como a arqueologia, a genealogia, a filologia, a numismática, a cronologia, dentre outras. É interessante ressaltar que a burguesia, ao se firmar como classe dominante, via por meio da História o seu momento de controlar o poder político, ou seja, lançar sua teoria para alcançar o poder, restando apenas a prática in loco. Tal fato aconteceu em diversos estados europeus, mas encontrou seu maior expoente na Revolução Francesa (SEVERINO, 1993). 


\section{A HISTÓRIA SOB O PRISMA POSITIVISTA}

A ideologia iluminista foi o grande instrumento da burguesia revolucionária: a escola econômica clássica inglesa com Adam Smith (1723-1790) e os teóricos franceses, principalmente Voltaire (1694-1778) e Montesquieu (1689-1755), são os grandes nomes dessa vertente epistemológica. Em meados do século XX, a linha burguesa da filosofia encontra no positivismo um conjunto de ideias que constituiriam o arcabouço dos seus anseios na figura do filósofo Isidore Auguste Marie Comte (1798-1857).

O positivismo, herança do paradigma newtoniano-cartesiano, apresenta um modelo de ciência essencialmente descritivo, bastante aproximado das ciências naturais, em que o mundo natural não se separa do social. Consequentemente, as leis descobertas pela ciência servem até mesmo para explicar as sociedades humanas. Partindo da indução e da experimentação, apenas o que é visível é tido como cognoscível e, portanto, verdadeiro. A religião e seus dogmas como critérios de verdade perdem sua autenticidade e os santos cedem lugar aos heróis, e quem traz estes como modelos patrióticos é a História. A política, a diplomacia, as guerras vão se constituir nos objetos de estudos dessa corrente de pensamento.

O cientificismo e o antropocentrismo são as suas principais características, por isso a História positiva enfatiza o feito dos grandes homens, o particular, os sacrifícios, associando figuras heroicas aos interesses das classes dominantes. Podemos demonstrar como exemplo a proclamação da república no Brasil, na qual o positivismo é bem recebido pelas elites. Como se sabe, esse episódio foi uma manobra da burguesia cafeeira aliada ao exército para tomar o poder político e reger o futuro do país, não significando rupturas nem transformações para a população comum, basicamente a rural e urbana desprovida de propriedade. Era por meio da História e do nacionalismo forjado de culto à nação, aos símbolos e personagens (Brasil, Tiradentes, hino nacional e bandeira nacional com o lema positivista "ordem e progresso") que as elites procuravam justificar para o restante do povo um novo sistema de governo que "teoricamente" deveria estar fundado nos princípios idealizados da soberania popular (Fausto, 1985). 
Essa História é factual, é apenas uma narrativa em que a análise e a interpretação dos fatos não cabem a ela.

Em matéria sociológica, Comte investe contra as teorias revolucionárias, e prega a necessidade de manter-se o "equilíbrio" social e a ordem. Esse mesmo ponto de vista é endossado por seu discípulo, Herbert Spencer (1820-1903), que identifica o organismo social com o organismo biológico, todos os membros da sociedade, à semelhança das partes do corpo humano e das funções orgânicas, devem subordinar-se a instâncias "superiores". O positivismo, em sua essência, desenvolve a doutrina do progresso, que vem do educador francês Jean-Antoine Condorcet (1743-1794), para quem a história sucede-se em movimento contínuo; e, a cada época, em grau mais elevado, projeta-se adiante, em progressão infinita, sob a égide da razão. Trata-se da razão pregada pelos arautos "ilustrados" dos ideais da burguesia, então revolucionária (SUCUPIRA 1984, p. 89).

A filosofia positivista se colocou no extremo oposto da especulação pura, exaltando, sobretudo, os fatos que podem ser observados, não aceitando outro tipo de realidade e ignorando os estados mentais. O sistema filosófico de Comte constitui-se basicamente de três eixos fundamentais:

1) A lei dos três estágios de desenvolvimento do pensamento humano: as fases do pensamento teológico, metafísico e positivo;

2) A lei da subordinação da imaginação à observação;

3) A lei enciclopédica de classificação das ciências.

As consequências dessas teses ou "leis" do positivismo para a epistemologia da História, segundo Cardoso (1981, p. 32), são de fundamental importância, pois nelas encontra-se:

Em primeiro lugar, a afirmação dos fatos - seu estabelecimento através da crítica erudita das fontes - como tarefa primordial. Por outro lado, um certo pessimismo quanto à possibilidade de explicar tais fatos através de leis. Como pode ser observado, na lista de Comte não figura a história; os fatos históricos, a cuja coleta se dedica ao historiador, eram vistos como a matéria-prima da sociologia, esta sim capaz de descobrir nexos legais entre os fatos sociais. Esta relação história/sociologia foi aceita pela maioria dos historiadores positivistas, essencialmente preocupados 
com a acumulação de fatos estabelecidos segundo critérios rigorosos de erudição crítica.

No século XIX, encontramos uma fase de afirmação dos nacionalismos europeus e de conflitos daí decorrentes. Os estados nacionais clássicos, como a França e a Inglaterra, assim como os estados ainda em processo de unificação, como a Itália e a Alemanha, vão estimular o interesse pelo estudo de sua História Nacional.

Via de regra, os nacionalistas demonstram grande orgulho pela História de seu povo e, muitas vezes, julgam que sua nação foi especialmente escolhida por Deus ou pelo destino fantástico. Tal como uma religião, o nacionalismo daria ao indivíduo um senso de comunidade. Desse modo, no século XIX, momento em que o cristianismo se fragilizava, o nacionalismo se tornava uma nova força. Esse sentimento nacional alçava novos mitos, mártires e dias "sagrados" que estimulavam reverência.

Os liberais também tentavam interpretar o nacionalismo. Consideravam a luta pela soberania nacional uma extensão da luta pelos direitos do indivíduo. Não pode haver liberdade, afirmavam os nacionalistas, se as pessoas não forem livres para ter um governo próprio em sua própria terra. Os liberais nacionalistas reivindicavam a unificação da Alemanha e da Itália, o renascimento da Polônia, a libertação da Grécia do domínio turco e a concessão de autonomia aos húngaros pelo império Austríaco, almejavam, enfim, uma Europa com estados independentes, com base na nacionalidade (FERNÁNDEZ, 1997).

Os países que procuravam estabelecer suas independências, os estados que pretendiam suas unificações e até mesmo as nações clássicas, começaram a levantar um rol de documentações para resgatar o seu passado. O exemplo mais visível em que podemos perceber o utilitarismo da História e seus métodos positivistas diz respeito à Alemanha que, se preocupando com a exaltação do seu nacionalismo, vai pesquisar, sobretudo, seu passado medieval e valorizar sua origem germânica. A Prússia foi o agente da unificação alemã, estimulando o nacionalismo dos povos germânicos contra inimigos em comum, como a Dinamarca, a Áustria e a França. A História caracterizava um modo de veiculação ideológica da burguesia, que almejava 
a unificação dos mercados e territórios germânicos para estimular sua incipiente industrialização.

Borges (2003, p. 32) considera que: "Dentro dessa visão nacionalista se encaixam alguns historiadores que são classificados como românticos, pois, dotados de uma certa contemplação sentimental da história, procuram uma volta ao passado cheia de nostalgia."

Nesse sentido, aparecem os historiadores alemães que pretendiam transformar a História em ciência. Mas esses historiadores não estavam querendo uma ciência qualquer, senão uma que possuísse o mesmo rigor das ciências exatas, como se fosse calcada em verdades absolutas e imutáveis e regida por leis universais. Com essa finalidade, o trabalho do historiador se centraliza numa voraz crítica das fontes, visando ao levantamento criterioso dos fatos e à sua quantificação. Acreditava-se que somente a História do quantitativo era científica. Os quantificadores negligenciam obstinadamente tudo o que tem de incerto, de subjetivo.

O maior nome dessa tendência, chamada "escola científica alemã", é Leopold Ranke, cuja frase famosa exprime toda uma forma de contar a história imperante no século: era preciso levantarem-se os fatos "como eles realmente se passaram". Seu trabalho é exigente, seguro, mas essa linha de orientação vai acabar dando força ao positivismo histórico, iniciado no século passado, mas com uma enorme influência até hoje (BORGES, 2003, p. 33-34).

Para os historiadores positivistas, os fatos levantados se encadeiam, assim como no mundo mecanicista moderno, numa relação determinista de causas e consequências, sendo a História por eles escrita uma sucessão de acontecimentos isolados. O passado se torna, mediante esse viés, algo morto, e em nada se relaciona com o presente.

\section{AS CONTRIBUIÇÕES DO MARXISMO PARA A HISTÓRIA}

Ao mesmo tempo em que o positivismo de Comte se transformava na "bíblia" de muitos historiadores, surgiram, nessa época, dois pensadores que iriam causar uma verdadeira revolução no campo do conhecimento, mostrando novas formas de 
interpretar as sociedades, o passado e o tempo presente. Esses pensadores eram Karl Marx (1818-1883) e Friedrich Engels (1820-1895).

No país mais rico do mundo, a Inglaterra, a luta pelos direitos de participação política dos trabalhadores cabia, então, ao movimento cartista. Esse cenário de um movimento operário ainda em seus primórdios está descrito em várias partes da obra de Marx - especialmente em O Manifesto Comunista e O Capital - fundamentais para entender o pensamento materialista dialético e histórico, que exerceria influência em grande parte do mundo nos anos seguintes. Marx tornou-se um historiador do seu próprio tempo e pensava este tempo para mudá-lo, como conclui Chesneaux (1995, p. 48): "Marx parte diretamente do presente (...) pensar historicamente o presente para mudá-lo, pois procurou de forma incansável entender a sociedade em que vivia."

Ainda hoje podemos perceber que a influência do marxismo e seu impacto no mundo intelectual contemporâneo são imensos.

(...) É evidente que na atualidade um historiador, por pouco preparado que seja (...), está inevitavelmente impregnado do modo marxista de pensar, de comparar os fatos e os exemplos; e isto ocorre ainda que nunca tenha lido uma linha de Marx, mesmo que se considere um fervoroso "antimarxista" em todos os sentidos, salvo no científico. Muitas ideias que Marx expressou com maestria penetraram, há muito tempo, no fundo comum que constitui o caudal intelectual de nossa geração (FEBVRE, 1935, p. 621).

A respeito da influência marxista no campo da historiografia, destaca-se três pontos importantes:

1) O estímulo a estudos de processos econômicos e sociais em longo prazo, incluindo uma análise das consequências sociais das transformações tecnológicas e econômicas;

2) Um renovado interesse pela pesquisa sobre classes sociais e suas relações, assim como sobre o papel dos movimentos de massa na História; 
3) Uma crescente preocupação com os problemas de interpretação e, especialmente, com o estudo das leis ou dos mecanismos de evolução das sociedades, bem como por sua comparação.

O pensamento marxista compreende, precisamente, três aspectos principais: o materialismo dialético, o materialismo histórico e a economia política, influenciados basicamente pelo idealismo clássico alemão (Kant, Fichte, Hegel, Schelling), o socialismo utópico (Saint-Simon e Fourier, na França e Owen, na Inglaterra) e a economia política inglesa (Ricardo e Smith).

A consciência para os materialistas seria produto da matéria, permitindo que o mundo se reflita nela, assegurando ao homem a possibilidade de compreensão do universo. A ideia materialista de mundo reconhece que a realidade existe independente da consciência.

O materialismo dialético é a base filosófica do marxismo e procura buscar explicações coerentes, lógicas e racionais para os fenômenos da natureza, da sociedade e do pensamento. Mas o materialismo dialético não tem somente como base de seus princípios a matéria, a dialética e a prática social, como também aspira ser a teoria orientadora da revolução do proletariado.

Marx e Engels deram o golpe decisivo no velho hábito mental de isolar o objeto de suas relações naturais - depois de erradicadas suas contradições implícitas característica de todo pensamento anticientífico. A esse estilo de pensamento, Marx e Engels denominaram de metafísico.

A aplicação do método dialético à interpretação da História e da sociedade denominase materialismo histórico, sendo este que estuda as leis sociológicas que caracterizam a vida social, a sua evolução histórica e a prática cotidiana dos homens no desenvolvimento da humanidade. O materialismo histórico ressalta a força das ideias, capaz de introduzir mudanças nas bases econômicas que as originaram. Por esse motivo, destaca a ação dos partidos políticos, dos agrupamentos humanos, dentre outros. 
De maneira geral, pode-se dizer que a concepção materialista apresenta três características importantes. A primeira delas é a da materialidade do mundo, a segunda ressalta que a matéria é anterior à consciência. Isso significa reconhecer que a consciência é um reflexo da matéria e que ela existe objetivamente e se constitui numa realidade objetiva. E, por último, o materialismo afirma que o mundo é cognoscível.

O método dialético materialista apresenta-se, pois, como um instrumento potencialmente revolucionário de investigação e de análise. Essa característica exprime-se no modo de conduzir a pesquisa de contradições básicas e na capacidade de encontrar meios justos de superação. O início de qualquer processo contraditório dá-se sempre pela ação do elemento negativo. Da ação recíproca do sim e do não, dos prós e contras, em que o elemento que nega evolui para a afirmação de si mesmo e, ao mesmo tempo, nega seu "oposto", abrindo caminho para uma determinação mais elevada.

Qualquer proposição se apresenta em seu estado original sob a forma positiva ou tese. Em fase subsequente, emerge o desdobramento em sim e não ou antítese. $\mathrm{Na}$ terceira e última fases, a antítese é por sua vez negada, dando lugar a uma terceira proposição - a síntese - resultado da negação não apenas da tese como da antítese obtido por meio da dupla negação ou negação da negação. Do ponto de vista dialético, causas externas e internas correlacionam-se entre si e não é possível separá-las, a não ser abstratamente em termos de lógica formal. A diferença entre ambas as causas está em que as forças externas são a condição das mudanças, e as internas, a base dessas mudanças: as primeiras agem por intermédio das segundas.

O critério que decide sobre o que se entende por verdade objetiva é resumido por Marx em uma crítica a Feuerbach (1804-1872) de que a questão de saber se uma verdade objetiva corresponde ao pensamento não é uma questão teórica, mas prática. O homem deve demonstrar na prática a verdade, isto é, a realidade e o poder, o exterior de seu pensamento. 
Quando Platão dividia sua República em duas partes - uma que dirige e pensa e outra que executa concretamente o trabalho - mostrava ao mesmo tempo a realidade de uma oposição inelutável entre o trabalho intelectual e o trabalho manual.

A dialética materialista corrigiu esse desvio, restabelecendo a relação entre o pensamento ordenador e a realidade material, a continuidade entre as ciências do homem e as ciências da natureza: aquilo que fora preocupação do homem isolado adquiriu expressão como atividade de toda uma coletividade. Somente a práxis põe o pensamento em contato com as realidades objetivas. Em primeiro lugar, o conhecimento é de ordem social. Em segundo lugar, na vida social descobrem-se outros seres semelhantes a nós, que agem sobre nós, do mesmo modo que agimos sobre eles. O conhecimento - em terceiro lugar - tem caráter histórico. Parte-se do que se ignora, seguindo longo e difícil caminho ascensional, antes de atingir-se a verdade.

A atividade humana nunca se separa das coisas; em tudo penetra, desvendando a intimidade sempre mais profunda do real; e, no processo de investigação, visando ao domínio das coisas, o homem se desenvolve e se transforma (SUCUPIRA, 1984).

Na visão de Marx (1971, p. 26), a sociedade burguesa, como "a mais complexa e desenvolvida organização histórica da produção", dá-nos a chave da explicação das formas organizadas anteriormente:

A sociedade burguesa é a mais complexa e desenvolvida organização histórica da produção. As categorias que expressam suas condições e a compreensão de sua organização permitem, ao mesmo tempo, compreender a organização e as relações de produção de todas as formas de sociedades passadas, sobre cujas ruínas e elementos ela foi edificada e cujos vestígios, ainda não superados, continuam arrastando, enquanto meros indícios anteriores desenvolveram nela sua plena significação, etc. (idem).

Podemos perceber que, para Marx, a explicação do passado depende da clara estruturação do presente e, estudando a sociedade capitalista burguesa, esta criaria bases para sua própria superação. Com a consolidação da burguesia como classe dominante, as divergências com as classes subalternas (proletariado) seriam 
intensificadas, criando bases para uma revolução que inverteria radicalmente a estrutura social.[3] Com esse pensamento, Marx cunhou a ideia de que a História das sociedades é a História das lutas de classe e de que estas constituem o motor da História. Segundo Borges (2003, p. 37) "Para Marx e Engels a História é um processo dinâmico, dialético, no qual cada realidade social traz dentro de si o princípio de sua própria contradição, o que gera a transformação constante da História".

É nesse momento que toda epistemologia da História positivista encontra sua mais radical negação: a História não é mais tida como pronta, acabada, mas produto das ações humanas sobre o mundo, então, passível de transformação. Ora, se a História é feita pelos homens, estes a transformam e não são estes apenas transformados por ela.

Os homens fazem sua história, quaisquer que sejam os rumos desta, ao perseguir cada qual seus fins próprios propostos conscientemente; e a resultante destas numerosas vontades, projetadas em diferentes direções, e de sua múltipla influência sobre o mundo exterior, é precisamente a história (ENGELS, 1985, p. 390).

Está nessa afirmação de Engels a grande herança do pensamento histórico marxista: o homem é um ser histórico, faz História, daí esta deve estar centrada na própria atividade humana, a qual somente é produzida no âmbito coletivo. Enquanto a historiografia tradicional enfatiza a História do passado e do particular, o pensamento marxista indica que o historiador parte do presente, de suas experiências práticas, de conceitos em vias de explicação, ou seja, seu procedimento vai do presente ao passado (LEFEBVRE, 1971).

Marx trabalha em sua obra analisando as transformações das sociedades antigas, que culminaram mais tarde na sociedade burguesa. Para isso, utiliza o conceito de modos de produção, que são articulações específicas e historicamente dadas, entre um tipo de organização definido das forças produtivas e as forças de produção correspondentes, daí os modos de produção asiático, comunista primitivo, escravista, feudal e capitalista. Já as forças produtivas correspondem aos elementos do processo do trabalho do ponto de vista de sua potencialidade produtiva, especialmente a força de trabalho e o meio de trabalho. 
Refletindo sobre o pensamento de Marx, Schaff (1967, p. 55-56) afirma que,

Muito ao contrário da filosofia alemã, que desce do céu para a terra, sobe-se aqui, da terra para o céu. Por conseguinte, não se parte do que dizem e imaginam os homens, nem dos homens pensados e imaginados, para chegar ao homem real; parte-se dos homens ativos, reais, e apresenta-se, tendo por base o seu processo vital real, o desenvolvimento dos reflexos ideológicos e ecos deste processo vital (...) Os homens reais fazem a história, e não a história se serve do homem para alcançar os seus objetivos. O homem cria a história, que é sua atividade.

O lugar ocupado pelo homem na História marxista é ao menos instigante. Essa nova forma de pensar desmonta o paradigma anterior ao propor uma História total, uma verdadeira História social, além de influenciar o surgimento, a partir do século XIX, de novas maneiras de produção do conhecimento histórico que, mesmo não sendo "totalmente" marxistas, contribuíram e continuam a contribuir para o aperfeiçoamento da História, como é o caso da corrente denominada Nova História, de me ocuparei a seguir.

\section{O CONHECIMENTO SOB A ÓTICA DOS ANNALES - A NOVA HISTÓRIA}

Segundo Reis (2000, p. 25), "uma escola histórica só pode se apresentar como "nova" se apresenta uma outra e original apresentação do tempo histórico." Além de uma nova representação do tempo, a Nova História foi importante por enfatizar novos métodos e percursos para a análise histórica, além de introduzir a hermenêutica como possibilidade de rompimento com o factual e de busca pela crítica na construção historiográfica. Jacques Le Goff, no prefácio da obra de Bloch (1997), postula que "os fatos históricos apenas se tornam história por meio da explicação que ele (o historiador) Ihes dá".

Os historiadores positivistas costumavam limitar a História à mera observação de fatos, sem a preocupação de dar-Ihes moralização, ornamento e sentido histórico. O trabalho do historiador positivista se delimitaria à recolha desses fatos, sem articulálos com a realidade humana em que foram produzidos. No positivismo, não existe a 
possibilidade de transformar as fontes históricas em problemas, já que ele se tinge do utilitarismo quando, em vez de fazer uma História total, reduz o trabalho histórico àquilo que lhe parece servir a ação[4].

É contra esse tipo de História, na qual a vida das sociedades é mutilada, em detrimento da História política, diplomática e militar, que um movimento conhecido como Annales tomaria forma.

Seus primeiros e notáveis idealizadores foram os franceses Lucien Febvre (18781956) e Marc Bloch (1886-1844) que apostavam na fundação de uma revista que viria a revolucionar a forma de ver e fazer História: em 1929 nascia a Annales d'histoire économique et sociale (Anais de história econômica e social)[5]. De acordo com Burke (1992), Bloch e Febvre, criadores da chamada Escola dos Annales, lideraram na França o movimento da "Nova História", uma História escrita como uma reação deliberada contra o paradigma tradicional, mais conhecido como História rankeana. Poderíamos também chamar esse paradigma (rankeano/positivista) de visão do senso comum da História, para assinalar que ele tem sido, com frequência, considerado a maneira de se fazer História, em vez de ser percebido como uma dentre várias abordagens possíveis do passado.

Burke (1992) afirma que, de acordo com o paradigma tradicional, a História refere-se essencialmente à política, adota a narrativa como forma de transmissão do conhecimento, interessa-se principalmente pelos feitos dos "grandes homens", utiliza como fontes os documentos emanados do governo e preservados em arquivos, condiciona as explicações a uma causalidade mecânica e considera a História como conhecimento objetivo, que deve ser apresentado sob a forma de fatos. Em contraposição, a Nova História interessa-se praticamente por toda atividade humana, estando preocupada com as pessoas comuns e com as mentalidades coletivas. Substitui ou complementa a narrativa com a análise das estruturas e considera como fontes todo tipo de vestígio deixado pelo homem, além de criticar as fontes oficiais, porque expressam o ponto de vista oficial.

Dentro das principais propostas desse movimento, podemos destacar as seguintes: 
1) Substituição da tradicional narrativa de acontecimentos por uma História-problema;

2) A busca pela História de todas as atividades humanas e não apenas a História política;

3) A colaboração com outras disciplinas, visando contemplar os dois primeiros objetivos, como a geografia, a sociologia, a psicologia, a economia, a linguística, a antropologia social, dentre outras;

4) A ampliação da utilização das fontes históricas para além da escrita (vestígios arqueológicos, tradições orais, gestos e costumes). Dessa forma, não é mais possível dividir a História em Pré-História e História, baseando-se na inexistência de documentos escritos no passado remoto. O historiador que estuda a difusão de uma cerâmica neolítica faz História exatamente como aquele que trabalha com uma fonte estatística moderna (FEBVRE, 1965).

Talvez pelas propostas citadas, Burke (1997) chegou a denominar, em um de seus livros, o movimento dos Annales como a Revolução Francesa da historiografia; e, de acordo com Le Goff (1988, p. 33-34),

Mais do que nunca, os "Annales" querem fazer entender. Colocar os problemas da história: "proporcionar uma história não automática, mas problemática". E, mais do que nunca, os problemas de uma história para o tempo presente, para nos permitir viver e compreender "num mundo em estado de instabilidade definitiva"

O movimento dos Annales foi revolucionário também ao reconhecer a ligação indissolúvel e necessária entre o presente e o passado, daí sua influência em muitos dos historiadores contemporâneos, que partem do viés de que a História não é apenas "passado", mas "presente", e um presente que apresenta problemas, cabendo ao historiador entendê-los.

Podemos dividir a História dessa corrente epistemológica em três fases. Em sua primeira fase, de 1920 a 1945, que se caracterizou por ser pequena, radical e subversiva, conduzindo uma guerra de guerrilhas contra a História tradicional, a História política e a História dos eventos. 
Na segunda fase do movimento, os historiadores dos Annales deram um "salto" na construção do conhecimento histórico ao se apoderarem de conceitos (particularmente estrutura e conjuntura) e novos métodos (especialmente a "História serial" das mudanças na longa duração), em que as contribuições de Fernand Braudel (1902-1985) foram importantíssimas.

Uma terceira fase se inicia por volta de 1968, profundamente marcada pela fragmentação, enfatizando a História sociocultural, o retorno à História política e à narrativa. Há uma incorporação de temas para os estudos, como sonho, corpo, odor, mulher, morte, sexo, dentre outros. Nesse momento, a psicologia é bastante utilizada, assim como a História econômica, da cultura popular e regional.

A fragmentação em demasia é a causa das críticas de alguns historiadores à terceira fase da Nova História, ou como diria Dosse (1992), uma "História em migalhas". A micro-história estaria tomando o lugar do todo, da macro-história. Os historiadores que se denominam "novos" se defendem ao afirmarem que mesmo partindo do particular, é possível buscar o conhecimento "global" de toda a História.

Uma proposta de interdisciplinaridade também faz parte de suas três gerações. Entretanto, a união da História com as Ciências Sociais é regulamentada por uma nova concepção de tempo, pois essa interdisciplinaridade seria incompatível com a temporalidade única, singular e irrepetível, linear e progressista da História tradicional. Ao se aproximarem das Ciências Sociais, os Annales mudaram a concepção quanto ao conceito de tempo histórico, mas sem perder a proposta de conhecer as mudanças humanas no tempo.

Os Annales de Braudel construíram o conceito de "longa duração", que ao mesmo tempo inspira e se diferencia do conceito de "estrutura social", das Ciências Sociais. De acordo com Vovelle (1982), na perspectiva da longa duração, o tempo histórico é representado como "dialética da duração". Os eventos são inseridos em uma ordem não sucessiva, simultânea, em que as mudanças humanas se endurecem, desaceleram-se. Antes de se pretender agir sobre a realidade, alterando-a, forçando- 
a a passar ao futuro, é preciso conhecer suas resistências. O tempo estrutural dos Annales é desacelerado.

Apareceu o que antes parecia não existir, quando a História era dominada por uma representação do tempo histórico, sucessivo e teleológico - um mundo histórico mais durável, mais estruturado, mais resistente às mudanças: as estruturas econômico-sociais-mentais. Nesse mundo, revelado pela inclusão da consideração da permanência no olhar do historiador, as ações humanas são percebidas como coletivas, inconscientes, anônimas, repetitivas; a documentação é involuntária, massiva, menos política e biográfica (REIS, 2000, p.35).

A História dos Annales não é mais movida pelo fim, mas sim pela articulação de permanência e mudança, não apresentando mais a imagem de progresso. Esta não apresenta mais uma estrutura uniforme, linear e homogênea. Há tempos múltiplos, observados nos processos construídos e reconstruídos pelo historiador. As sociedades, e cada uma individualmente, vivem em ritmos distintos e o seu presente não é centrado, mas uma coexistência tensa de durações múltiplas. O historiador reconstrói essas durações, coordena-as por meio do tempo, representando modelos e conceitos.

A Nova História, inspirada por uma crítica aos métodos positivistas, surge como uma espécie de renovação metodológica que dará à História um caráter científico. Podemos perceber ainda que, nos últimos trinta anos, a visão dos modos de produção pré-capitalistas modificou-se, justificando certa confluência entre o marxismo e a Nova História, mas, ao mesmo tempo, podemos notar que o marxismo, segundo Bois (1988), representou um imenso papel na própria renovação metodológica da História na medida em que procura analisar a sociedade de forma total, em que se deve apreender diversos aspectos da vida social, os quais a Nova História tende a analisar com frequência, como o caráter econômico, político, mental e social dessas sociedades.

\section{CONSIDERAÇÕES FINAIS}

A análise sobre o positivismo permite constatar um dilema metodológico na historiografia: influenciado pelo paradigma tradicional do conhecimento, o positivismo 
transformou-a em uma ciência objetiva, retirando de sua essência toda carga de criticidade e reflexão, também denominada de "possibilidade hermenêutica" (LE GOFF, 1988). Podemos citar como exemplo, não muito distante, a educação histórica. A História ensinada dentro das salas de aula possui, até hoje, uma grande influência do positivismo, da denominada História tradicional (BARCA, 2007).

O estudo do marxismo e da Nova História coadunam, cada qual a sua maneira, que dentro do processo de construção do conhecimento, existe a possibilidade de romper com as tradições positivistas, transformando a produção historiográfica em algo problematizador, crítico e reflexivo, podendo, quase como um dever moral, constituirse como ferramenta de transformação social.

Os novos paradigmas que explicam a nossa sociedade convidam-nos a prestar atenção aos mecanismos de construção histórica e a reconhecer que a História petrificada dos manuais se confundiu com àquela que era determinada pelos agentes que detinham o poder da produção da narrativa. No Brasil, por exemplo, dos envolvidos diretamente com a construção da memória nacional, através de uma historiografia oficial aduladora que remonta o período imperial, produzida através do Instituto Histórico e Geográfico Brasileiro.

Desde a sua instituição no século XIX como disciplina acadêmica, a História vem sendo vislumbrada como um dos principais arcabouços de propaganda das relações sociais em favor das elites. Reconhecer que a História busca apreender os homens e as mulheres não isolados do contexto material, mas vivendo em sociedade, conformando uma trama muito mais complexa do que as tramas políticas ou diplomáticas, é um grande passo em direção de uma nova compreensão epistemológica dessa ciência, a qual apercebe-se que os assuntos selecionados segundo a História oficial, respondem à uma visão particular de História, que tende a dificultar o diálogo com outras ciências, tão importante para o entendimento e reconstituição do passado.

Desconstruir narrativas arcaicas; desestruturar as formas tradicionais de se transmitir a História; reconhecer que o eixo político não é o único capaz de explicar a sociedade, 
nem é o eixo estruturante dessa ciência; considerar a forma ideológica que sustentou a visão da História dominante; identificar na História oficial a memória do poder; denunciar os pressupostos que estão por trás de determinado recorte ou seleção dos assuntos. Somente essas convicções permitirão 0 engajamento em novos posicionamentos frente ao passado e ao presente e, ao mesmo tempo, possibilitará a criação de novas estratégias para poder se pensar o que se constituiu sobre o passado, de uma outra maneira.

\section{REFERÊNCIAS}

ASHTON, Thomas Southcliff. A revolução industrial. Lisboa: Europa-América, 1971.

BARCA, Isabel. Marcos de consciência histórica de jovens portugueses. Currículo sem Fronteiras, v.7, n.1, pp.115-126, 2007.

BURCKHARDT, Jakob. A cultura do renascimento na Itália. São Paulo: Companhia das Letras, 1990.

BLOCH, Marc. Introdução à história. Portugal: Publicações Europa-América, 1997.

BOBBIO, Norberto. A era dos direitos. Rio de Janeiro: Campus, 1992.

BOIS, Guy. Marxismo e história nova. In: Le Goff, Jacques. A história nova. São Paulo: Martins Fontes, 1998.

BORGES, Vavy Pacheco. O que é história? São Paulo: Brasiliense, 2003.

BURKE, Peter. Cultura popular na Idade Moderna. São Paulo: Companhia das Letras, 1989.

. (org.). A escrita da história: novas perspectivas. São Paulo: Unesp, 1992.

A escola dos annales (1929-1989): a revolução francesa da historiografia. São Paulo: Unesp, 1997. 
CARDOSO, Ciro Flamarion. Uma introdução à história. São Paulo: Brasiliense, 1981.

CHESNEAUX, Jean. Devemos fazer tábula rasa do passado? São Paulo: Editora Ática, 1995.

DEMO, Pedro. Conhecimento moderno: sobre ética e intervenção do conhecimento. Petrópolis: Vozes, 1997.

DOSSE, François. A história em migalhas: dos "Annales" à "Nova História". São Paulo: Ensaio, 1992.

DUBY Georges. Idade Média, idade dos homens. São Paulo: Companhia das Letras, 1989.

ENGELS, Friedrich. A origem da família, da propriedade privada e do estado. São Paulo: Global, 1985.

FAUSTO, Boris (org.). História geral da civilização brasileira. São Paulo: Difel, 1985.

FEBVRE, Lucien. Techniques, sciences et marxisme, em Annales d'histoire économique et sociale, 끄 36, 1935.

. Combats pour I'Histoire. Paris: Colins, 1965.

FERNÁNDEZ, Antonio. História del mundo contemporáneo. Barcelona: Vicens Vives, 1997.

LEFEBVRE, Henri. La fin de l'histoire. Lisboa: Publicações Dom Quixote, 1971.

LE GOFF, Jacques. A civilização do ocidente medieval. Lisboa: Estampa, 1983.

. A história nova. São Paulo: Martins Fontes, 1988.

LEVI, Anthony. Guide to french literature: 1789 to the present. Chicago: Saint James, 1992. 
MARX, Karl. Elementos fundamentales para la crítica de la economia política. México: Siglo, 1971.

MORAES, Maria Cândida. O paradigma educacional emergente. Campinas: Papirus, 1997.

NORONHA, Olinda Maria. História da educação: sobre as origens do pensamento utilitarista no ensino superior brasileiro. Campinas: Editora Alínea, 1998.

REIS, José Carlos. Os Annales: a renovação teórico metodológica e "utópica" da história pela reconstrução do tempo histórico. In: Saviani, Demerval; Lombardi, José Claudinei; Sanfelice, José Luís (orgs). História e história da educação. Campinas: Autores Associados, 2000.

SEVERINO, Antonio Joaquim. Filosofia. São Paulo: Cortez, 1993.

SCHAFF, Adam. O marxismo e o indivíduo. São Paulo: Civilização Brasileira, 1967.

SUCUPIRA, Eduardo. Introdução ao pensamento dialético. São Paulo: Alfa-Omega, 1984.

THOMPSON, Edward Palmer. A miséria da teoria ou um planetário de erros: uma crítica ao pensamento de Althusser. Rio de Janeiro: Zahar, 1981.

VOVELLE, Michel. Idéologies, et mentalités. Paris: Maspero, 1982. . La mort et l'Occident: de 1300 à nos jours. Paris: Gallimard, 1983.

\section{APÊNDICE - REFERÊNCIAS DE NOTA DE RODAPÉ}

2. Direitos naturais defendidos pelos liberais, nos quais se enquadram a vida, a propriedade e o trabalho. Direitos que são veementemente defendidos pelos iluministas dos séculos XVII e XVIII. 
3. Durante a consolidação da Revolução Industrial na Europa, homens, mulheres e crianças eram submetidos às mais diversas formas de exploração. Na indústria têxtil inglesa, por exemplo, empregava-se crianças de até seis anos de idade, as jornadas de trabalho chegavam até 16 horas, as condições eram precárias e os acidentes nas fábricas frequentes (Ashton, 1971).

4. A ideia de que o conhecimento possui somente algum valor se associado a fins práticos é uma das heranças do paradigma positivista. No que diz respeito ao ensino, podemos, dentro das próprias universidades, observar a ênfase dada aos cursos que proporcionam alguma forma de acumulação de capital (hoje particularmente as ciências tecnológicas e de saúde). Sobre o assunto, vide Noronha (1998).

5. Com o decorrer dos anos, outros autores iriam integrar esse movimento, como: Fernand Braudel, Georges Duby, Jacques Le Goff e Emmanuel Le Roy Ladurie, os quais continuariam (e continuam) a contribuir para que a História avance em todos os sentidos. Já sobre a revista, esta possuiu mais três títulos além desse: Annales d'histoire sociale (1939-1942-45); Mélanges d'histoire Sociale (1942-4) e Annales: Économies, Societés, Civilisations (1946-).

Enviado: Junho, 2020.

Aprovado: Novembro, 2020. 